\title{
Analisis Pengaruh LED Inframerah Sebagai Pengawet Susu Formula Cair
}

\author{
${ }^{1}$ Muhammad Helmi Hakim, ${ }^{2}$ Ratika Sekar Ajeng Ananingtyas, ${ }^{3}$ Rosidi Azis \\ Universitas Nahdlatul Ulama Blitar, Indonesia \\ Email: ${ }^{1}$ helmi.hakim755@gmail.com, ${ }^{2}$ ratikasekar@gmail.com, \\ ${ }^{3}$ rosialfatih1953@gmail.com
}

\begin{tabular}{l}
\hline Tersedia Online di \\
\hline http://www.jurnal.unublitar.ac.id/i \\
ndex.php/briliant
\end{tabular}

\section{Sejarah Artikel}

Diterima pada 18 November 2020

Disetujui pada 20 Februari 2021

Dipublikasikan pada 28 Februari 2021

Hal. 157-162

\begin{tabular}{l}
\hline Kata Kunci: \\
\hline LED inframerah; Pangan; Bakteri; \\
Susu Formula
\end{tabular}

\section{DOI:}

http://dx.doi.org/10.28926/briliant. v3i4.590

\begin{abstract}
Abstrak: Penelitian ini dilakukan untuk menganalisis pengaruh LED inframerah sebagai potensi dalam pengawetan kualitas susu formula cair yang termasuk salah satu jenis pangan mudah rusak. Penelitian yang dilakukan adalah penelitian kuantitatif desain true experiment. Data yang diperoleh adalah data hasil uji TPC kelompok kontrol tanpa paparan 0 LED inframerah yang didiamkan selama 2,5 jam dan kelompok pemaparan dengan dipapari 15 LED inframerah juga selama 2,5 jam di tempatkan di atas botol susu formula cair. Hasil rata-rata nilai TPC untuk kelompok kontrol didapatkan 16,93 X $10^{5}$ CFU/mL. Sedangkan rata-rata nilai TPC untuk kelompok pemaparan didapatkan 2,7 X $10^{5}$ $\mathrm{CFU} / \mathrm{mL}$. Dari hasil analisis uji statistik inferensial One way-Anova post-hoc Tukey didapatkan nilai signifikansi sebesar $0,006<0.05$. Sehingga terdapat pengaruh yang signifikan pada susu formula cair yang dipapari LED inframerah terhadap penurunan jumlah bakteri dari hasil uji TPC.
\end{abstract}

\section{PENDAHULUAN}

Susu merupakan bahan pangan yang kaya akan nutrisi. Susu mengandung komposisi kimia yang lengkap terdiri atas protein, karbohidrat, lemak, vitamin dan mineral. Susu menjadi sarana potensial bagi penyebaran bakteri patogenik yang mudah tercemar. Kelengkapan komposisi kimia tersebut menjadi media yang baik bagi pertumbuhan mikroorganisme. Pertumbuhan mikroorganisme pada susu menyebabkan susu mudah rusak (Spreer E. 2017). Teknik penyajian susu yang tidak sesuai dengan standar dapat mengakibatkan potensi risiko terinfeksi bakteri patogen (Staphylococcus aureus, Escherichia coli, dan Salmonella sp) dan bakteri pembusuk (Micrococcus sp., Pseudomonas sp., dan Bacillus sp) (Suwito, 2016). Bakteri Bacillus cereus dapat tumbuh pada susu bubuk yang telah diseduh dan dibiarkan selama 2 jam (Pavic et al., 2005). Pertumbuhan Bacillus Cereus meningkat lebih cepat dalam susu bubuk yang telah dilarutkan dan disimpan pada suhu ruang (Becker et al., 1994). Susu yang terkontaminasi bakteri pembusuk dapat menimbulkan penyakit pada anak antara lain yaitu salmonelosis, listeriosis dan shigelosis (FSANZ, 2013). 
Penyimpanan susu formula cair yang disimpan baik dalam kondisi tertutup maupun terbuka dan dalam jangka waktu lama tidak baik untuk kesehatan bayi. Susu formula merupakan susu pengganti Air Susu Ibu (ASI) yang khusus dikonsumsi oleh bayi untuk menjadi sumber gizi sampai bayi diperkenalkan dengan makanan pendamping lainnya (BPOM, 2009). Kebanyakan seorang ibu masih menyimpan sisa susu formula yang tidak dihabiskan oleh bayinya. Risiko terinfeksi bakteri terhadap bakteri dapat meningkat seiiring dengan lama penyimpanan dan tempat penyimpanan susu (NHMRC, 2012). Kumar (2013) menjelaskan bahwa waktu penyimpanan susu formula bayi dalam bentuk cair berpengaruh terhadap pertumbuhan bakteri. Nilai Total Plate Count (TPC) meningkat baik pada wadah tertutup maupun wadah terbuka dalam setiap jamnya (Kumar, 2013).

Secara alami, bakteri menghasilkan endogen porfirin yaitu molekul penyerap cahaya yang bersifat fotosensitizier (peka terhadap cahaya). Setiap molekul porfirin mempunyai kemampuan menyerap cahaya yang berbeda tergantung pada panjang gelombang cahaya (Papageorgiou et al., 2000). Kombinasi cahaya dan fotosensitizier dengan spektrum yang sesuai akan menyebabkan fotoinaktivasi sel bakteri. Proses fotoinaktivasi diawali dengan mekanisme fotosensitasi yaitu penyerapan cahaya oleh porfirin yang selanjutnya mengaktivasi reaksi dalam substrat. Fotosensitasi ini bergantung pada jenis dan kuantitas dari porfirin sebagai molekul penyerap cahaya (Nitzan et al., 2004).

Proses fotoinaktivasi dapat diakibatkan dari paparan gelombang inframerah. Gelombang inframerah memiliki karakteristik sebagai cahaya yang mudah diserap material organik. Material organik dalam bakteri akan cepat menyerap cahaya inframerah saat terjadi proses penyinaran, sehingga kenaikan temperatur pada bakteri terjadi semakin cepat (Hamanaka, 2005). Mekanisme utama fotoinaktivasi bakteri adalah pemanasan langsung ke mikroorganisme oleh penyinaran termal (Dhirgo, 2013). Berdasarkan penelitian tersebut menunjukkan bahwa gelombang inframerah dapat menyebabkan fotoinaktivasi bakteri. Melihat potensi gelombang inframerah maka perlu diteliti untuk menganalisis pengaruh LED inframerah sebagai pengawet susu formula cair.

\section{METODE}

Metode pada penelitian ini yaitu penelitian kuantitatif desain true experiment dengan 6 buah sampel yang dipilih secara acak. Waktu pengambilan data dilakukan pada bulan 29 September 2020 sampai tanggal 7 November 2020 di kampus 1 Universitas Nahdlatul Ulama Blitar dan di laboratorium pusat dan halal center Universitas Islam Malang.

Tahapan penelitian diawali dengan melakukan preparasi alat dan bahan dengan membuat alat pemancar gelombang inframerah dari LED (Light Emitting Diode) inframerah. LED inframerah yang digunakan dalam penelitian ini adalah LED inframerah dengan panjang gelombang $940 \mathrm{~nm}$ yang ditempatkan di atas botol dot susu. Tahapan penelitian selanjutnya adalah tahap pengambilan data. Pada tahap ini, sampel dikelompokkan menjadi dua perlakuan yaitu pertama adalah kelompok kontrol tanpa paparan 0 LED inframerah yang didiamkan selama 2,5 jam dan yang kedua adalah kelompok pemaparan dengan dipapari 15 LED inframerah juga selama 2,5 jam pada posisi diatas botol susu formula cair, 
kemudian semua sampel diuji TPC (Total Plate Count) untuk mengetahui jumlah bakteri dalam susu formula cair.

Data yang diperoleh adalah data hasil uji TPC dari kelompok kontrol tanpa paparan atau 0 LED inframerah dan kelompok pemaparan dengan dipapari 15 LED inframerah yang juga selama 2,5 jam pada posisi diatas botol susu formula cair. Data hasil uji TPC dianalisis dengan uji statistik inferensial One way-Anova post-hoc Tukey untuk mengetahui pengaruh jumlah LED inframerah terhadap pertumbuhan bakteri susu formula cair.

\section{HASIL}

Dari hasil uji TPC, didapatkan data seperti tabel dibawah:

Tabel 1. Hasil uji TPC

\begin{tabular}{|c|c|c|}
\hline $\begin{array}{c}\text { Perlakuan } \\
\text { (Jumlah LED Inframerah) }\end{array}$ & Sampel & TPC (CFU/mL) \\
\hline \multirow{4}{*}{$\begin{array}{c}\text { Tanpa dipapari } \\
\text { (0 LED Inframerah) }\end{array}$} & T.D 1 & $14,8 \times 10^{5}$ \\
\hline & T.D 2 & $22 \times 10^{5}$ \\
\hline & T.D 3 & $14 \times 10^{5}$ \\
\hline & Rata-rata & $16,93 \times 10^{5}$ \\
\hline \multirow{4}{*}{$\begin{array}{c}\text { Dengan dipapari } \\
\text { (15 LED Inframerah) }\end{array}$} & D.D 1 & $1,5 \times 10^{5}$ \\
\hline & D.D 2 & $2,4 \times 10^{5}$ \\
\hline & D.D 3 & $4,2 \times 10^{5}$ \\
\hline & Rata-rata & $2,7 \times 10^{5}$ \\
\hline
\end{tabular}

\section{Keterangan : T.D (Tanpa Dipapari)}

D.D (Dengan Dipapari)

Tabel 1 menunjukkan hasil uji TPC tiap sampel pada dua kelompok perlakuan. Pada kelompok kontrol tanpa dipapari gelombang inframerah (0 LED Inframerah) didapatkan hasil uji TPC untuk sampel T.D 1 sebesar 14,8 x $10^{5}$ CFU/mL, sampel T.D 2 sebesar $22 \times 10^{5} \mathrm{CFU} / \mathrm{mL}$ dan sampel T.D 3 sebesar $14 \mathrm{x}$ $10^{5} \mathrm{CFU} / \mathrm{mL}$. Sedangkan pada kelompok dengan dipapari gelombang inframerah (0 LED Inframerah) didapatkan hasil uji TPC untuk sampel D.D 1 sebesar 1,5 $\mathrm{x}$ $10^{5} \mathrm{CFU} / \mathrm{mL}$, sampel D.D 2 sebesar 2,4 x $10^{5} \mathrm{CFU} / \mathrm{mL}$ dan sampel D.D 3 sebesar $4,2 \times 10^{5} \mathrm{CFU} / \mathrm{mL}$.

Dari data hasil uji TPC tersebut, kemudian dilakukan uji statistik inferensial One way-Anova post-hoc Tukey untuk mengetahui pengaruh perlakuan antara tanpa paparan gelombang inframerah (0 LED Inframerah) yang didiamkan selama 2,5 jam dengan dipapari gelombang inframerah (15 LED inframerah) yang juga selama 2,5 jam terhadap pertumbuhan bakteri susu formula cair. Hasil dari uji statistik inferensial One way-Anova post-hoc Tukey dapat dilihat pada tabel 2 di bawah ini:

Tabel 2. Hasil Uji Statistik Inferensial One way-Anova post-hoc Tukey

\begin{tabular}{|ll|r|r|r|r|l|}
\hline & Sum of Squares & df & Mean Square & F & Sig. \\
\hline TPC & Between Groups & 30388,17 & 1 & 30388,17 & 28,53 &, 006 \\
& Within Groups & 4260,67 & 4 & 1065,17 & & \\
Total & 34648,83 & 5 & & & \\
\hline
\end{tabular}


Tabel 2 menunjukan hasil uji statistik inferensial One way-Anova post-hoc Tukey. Didapatkan nilai signifikansinya sebesar $0,006<0.05$, sehingga $\mathrm{H}_{1}$ diterima dan $\mathrm{H}_{0}$ ditolak.

\section{PEMBAHASAN}

Hasil uji TPC pada Tabel 1 menunjukan terdapat penurunan jumlah bakteri antara susu formula cair yang dipapari (15 LED inframerah) selama 2,5 jam dibandingkan dengan kelompok kontrol tanpa dipapari gelombang inframerah (0 LED Inframerah) atau didiamkan yang juga selama 2,5 jam. Hasil rata-rata dari tiga sampel pada kelompok kontrol tanpa paparan gelombang inframerah (0 LED Inframerah) didapatkan nilai TPC 16,93 X $10^{5} \mathrm{CFU} / \mathrm{mL}$. Sedangkan rata-rata dari tiga sampel pada kelompok perlakuan dengan dipapari (15 LED inframerah) didapatkan nilai TPC 2,7 x $10^{5} \mathrm{CFU} / \mathrm{mL}$. Adanya penurunan jumlah bakteri pada kelompok sampel dipapari dibandingkan dengan kelompok sampel tanpa dipapari gelombang inframerah dari LED inframerah, menunjukkan terdapat proses fotoinaktivasi yang diakibatkan dari paparan gelombang inframerah.

Gelombang inframerah memiliki karakteristik sebagai cahaya yang mudah diserap oleh material organik dalam bakteri. Material organik dalam bakteri akan cepat menyerap cahaya inframerah saat terjadi proses penyinaran, sehingga kenaikan temperatur pada bakteri terjadi semakin cepat (Hamanaka, 2005). Mekanisme utama fotoinaktivasi bakteri adalah pemanasan langsung ke mikroorganisme oleh penyinaran termal (Dhirgo, 2013).

Pada Tabel 2 hasil uji statistik inferensial One way-Anova post-hoc Tukey untuk untuk mengetahui pengaruh perlakuan antara tanpa paparan gelombang inframerah (0 LED Inframerah) yang didiamkan selama 2,5 jam dengan dipapari (15 LED inframerah) yang juga selama 2,5 jam terhadap pertumbuhan bakteri susu formula cair, didapatkan nilai signifikansinya $0,006<0.05$, sehingga kita menerima $\mathrm{H}_{1}$ dan $\mathrm{H}_{0}$ ditolak. Dengan demikian intepretasi dari hasil tersebut menunjukkan terdapat pengaruh antara pemberian paparan dari LED inframerah dengan jumlah 15 LED selama 2,5 jam terhadap jumlah bakteri pada susu formula cair. Hasil uji analisis ini menunjukan hasil yang identik dengan penelitian yang dilakukan oleh Khorur Ro'isah pada tahun 2019 yaitu menguji pengaruh pemaparan Light Emitting Dide (LED) terhadap pertumbuhan bakteri Listeria monocytogenes $\mathrm{Ph}$, dan organoleptik pada jus apel. Hasil penelitian menunjukan bahwa Light Emitting Dide (LED) mampu menurunkan jumlah bakteri Listeria monocytogenes pada jus apel, dimana jumlah bakteri Listeria monocytogenes sebelum diberi paparan Light Emitting Dide (LED) jumlah koloni sebesar 23,1 x $10^{8} \mathrm{CFU} / \mathrm{ml}$ dan setelah dipapari Light Emitting Dide (LED) dengan intensitas $125 \mathrm{Mw} / \mathrm{cm}^{2}$ selama 50 menit jumlah koloninya menjadi 3,3 x $10^{8} \mathrm{CFU} / \mathrm{ml}$ dan persentase penurunan jumlah bakteri sebesar 85,7 \% (Ro'isah, 2019). 


\section{KESIMPULAN}

Dari hasil penelitian ini untuk mengetahui pengaruh penggunaan LED inframerah sebagai potensi dalam pengawetan kualitas susu formula cair yang termasuk salah satu jenis pangan mudah rusak, dapat disimpulkan bahwa pemberian paparan LED inframerah dapat mempengaruhi penurunan jumlah bakteri antara susu formula cair yang dipapari (15 LED inframerah) selama 2,5 jam dibandingkan dengan tanpa dipapari gelombang inframerah (0 LED Inframerah) atau didiamkan yang juga selama 2,5 jam sebagai sampel kontrol.

\section{SARAN}

Agar mendapatkan hasil penelitian yang maksimal terhadap pengaruh LED inframerah sebagai potensi dalam pengawetan kualitas pangan yang mudah rusak maka disarankan melakukan penelitian lanjutan dengan membuat variasi lama paparan.

\section{DAFTAR RUJUKAN}

Astuti, Suryani Dyah dkk. 2011. Potensi Photodinamik inaktivasi Staphylococcus aureus dan Vibrio cholerae dengan Endogen Photosensitizer pada Penyinaran LED Biru (430 \pm 4) $\mathrm{nm}$ dan Merah (629 \pm 6) $\mathrm{nm}$. Surabaya: Universitas Airlangga

Badan Pengawas Obat dan Makanan Republik Indonesia. 2009. Peraturan Kepala Badan Pengawas Obat dan Makanan Nomor HK.00.06.1.52.4011 tentang Penetapan Batas Maksimum Cemaran Mikroba dan Kimia Dalam Makanan, Badan Pengawas Obat dan Makanan Republik Indonesia, Jakarta.

Becker EW. 1994. Microalgae Biotechnology and Microbiology. Melbourne: Cambridge University Press. 293 hal.

Dhirgo, Adji. 2013. Perbandingan Efektivitas Sterilisasi Alkohol 70\%, Inframerah,Otoklaf, dan Ozon Terhadap Pertumbuhan Bakteri Bacillus subtilis. Yogyakarta: Universitas Gajah Mada.

Food Strandards Australia New Zealand. 2013. Agents of Foodborne Illness, $2^{\text {nd }}$ ed, Food Standards Australia New Zealand, Canberra.

Grossweiner LI. 2005. The Science of Phototherapy: An Introduction. USA: Springer

Hadiwiyoto. 1994. Pengujian Mutu Susu Dan Hasil Olahannya. Yogyakarta: Liberty. Hal: 5.

Hamanaka, Daisuke. 2005. Effect Of The Wavelength Of Infrared Heaters On The Inactivation Of Bacterial Spores At Various Water Activities. International Journal of Food Microbiology: Elsevier

Hamblin dan Hasan T. 2003. Photodynamic therapy: a new antimicrobial approach to infectious disease. PPS (http://www.rsc.org/pps)

Jorgensen, H.J., T. Mork, H.R. Hogasen, and L.M. Rorvik. 2005. Enterotoxigenic Staphylococcus aureus in bulk milk in Norway. J. Appl. Microbiol. (99): 158-166. 
Kumar, P. 2013. Pengaruh Lamanya Penyimpanan Susu Formula Bayi pada Suhu Kamar Terhadap Pertumbuhan Mikroorganisme. Universitas Sumatera Utara, Sumatera Utara.

National Health and Medical Research Council 2012. Eat for Health Infant Feeding Guidelines Information for Health Workers, National Health and Medical Research Council, Canberra.

Nicoresu, I et al. 2012. Pulsed Light Inactivation Of Bacillus Subtilis Vegetative Cells In Suspensions and Spices. Food Control Journal: Elsevier

Nitzan, Divon MS, Shporen E, Malik Z. 2004. ALA Induced Photodynamic Effect on Gram Positive and Negative bacteria. Journal of Photochemistry \& Photobiology.

Pavic, S., Brett, M., Petric, I., Lastre, D., Smoljanovic, M., Atkinson, M., et al. 2005. An outbreak of food poisoning in a kindergarten caused by milk powder containing toxigenic Bacillus subtilis and Bacillus licheniformis, pp 20-22.

Ro'isah, Khoirur. 2019. Pengaruh pemaparan Light Emitting Dide (LED) terhadap pertumbuhan bakteri Listeria monocytogenes $\mathrm{Ph}$, dan organoleptik pada jus apel. Skripsi. Jurusan Fisika. UIN Maulana Malik Ibrahim Malang

Steel, C.J. dan J.H. Torrie.1995. Prinsip dan Prosedur Statistik. PT. Gramedia. Jakarta.

Sudono, A., F. Rosdiana dan S. Budi. 2003. Beternak Sapi Perah. PT. Agromedia Pustaka, Jakarta.

Suwito, widodo. 2016. Bakteri yang Sering Mencemari Susu: Deteksi, Patogenesis, Epidemiologi, dan Cara Pengendaliannya. Balai Pengkajian Teknologi Pertanian .Yogyakarta: Yogyakarta.

Winarno F.G. 2004. Kimia Pangan dan Gizi. PT Gramedia Pustaka Utama. Jakarta. 